\title{
RETAINED EXCESS RESIN CEMENT AROUND TISSUE LEVEL IMPLANTS USING TWO DIFFERENT CEMENTATION TECHNIQUES (AN IN VITRO STUDY)
}

\author{
Diana M. Abdelazeem ${ }^{1} B D S$, Samir A. Koheil ${ }^{2} P h D$, Wegdan M. Abdel-Fattah² $P h D$
}

\begin{abstract}
INTRODUCTION: The main disadvantage of a resin cement-retained implant fixed prosthesis is the entrapment of residual excess cement in the peri-implant tissues. Remaining cement has been shown to be associated with peri-implant inflammation and bleeding.

OBJECTIVES: The aim of this study was to detect the retained excess resin cement around tissue level dental implants, and to determine which method of cementation will show less amount of retained excess cement.

MATERIALS AND METHODS: Fourteen tissue level implants (OCO Biomedical, Inc. Albuquerque, U.S.A.) were embedded in drilling models (Salvin Dental Specialties, Inc. Charlotte, U.S.A.) having rubber surface covering simulating the gingiva. Fourteen metal copings were fabricated (Realloy e.k, Sliemsdyk 50, Krefeld, Germany). RelyX U200 (TM3M, ESPE Dental Products. St. Paul, U.S.A.) dual cure resin cement was used for cementation of the metal copings to the implants. The implants were divided into two main groups according to cementation technique $(n=7)$ : Group $(A)$ : non vented tack curing of the excess cement for three seconds then the excess resin cement was carefully removed. Group (B): occlusal vent was performed on the occlusal surface of the metal copings to allow excess cement to be extruded through the vent hole; then all the excess cement from the vent and margins was removed. The rubber coverage was removed and the retained cement was collected and the net weight of the retained cement was determined.

RESULTS: Mann-Whitney U test revealed a statistically significant differences $(\mathrm{p}<0.05)$ between the non-vented tack cure and the occlusal vent groups in the amount of retained excess cement, with the occlusal vent group $(B)$ had more excess cement percentage than the non vented tack cure group (A).

CONCLUSIONS: Tack curing of the excess resin cement during the cementation of implant-supported restorations might reduce the cement residue, but still couldn't remove the problem of excess resin cement around dental implants.

KEYWORDS: Tissue level implant, excess resin cement, tack cure, occlusal vent.
\end{abstract}

1. B.D.S. Faculty of Dentistry Alexandria University and Instructor of Conservative Dentistry, Alexandria University, Alexandria, Egypt.

2.Professor of Conservative Dentistry, Faculty of Dentistry Alexandria University

Corresponding author:

E-mail:dr.diana.mohamed@gmail.com

\section{INTRODUCTION}

Cement retained restorations is considered the most commonly used implant fixed prosthetic option. However, cement retained implant restorations have limitations. Complete removal of the excess cement is generally a challenge, especially with subgingival margins (1-3). Residual cement may lead to peri-implantitis and implant failure $(1,4,5)$.

Different cement types have been used to lute fixed restorations on implant abutments (6). Resin cements are increasingly used nowadays because of their high retention, decreased dissolution in the oral fluids, and the ability to reduce microleakage compared with other traditional luting cements (7-10). However, the complete removal of resin cement is difficult, and scratches from the removal of excess cement with sharp instruments leads to the increase of the surface roughness of the implant surface $(11,12)$.

Several techniques to minimize the excess cement have been proposed in the literature, such as partial photo polymerization of the cement before removal of the excess (tack curing) (13) and crown venting techniques (14).

The purpose of the present study was to find a technique for cementing implant-supported restorations without leaving any excess cement, and if excess cement was found to determine which method of cementation will show less amount of retained excess resin cement around tissue level dental implants.

The null hypothesis was that there is no difference between the non-vented tack cure and the occlusal vent technique in the amount of the excess cement retained around tissue level dental implants.

\section{MATERIALS AND METHODS}

Two special models (Salvin Dental Specialties, Inc. Charlotte, U.S.A.) simulating the bone of the mandible in the biomechanical properties with $1.5 \mathrm{~mm}$ rubber surface simulating the gingiva were used for this study. Fourteen (4.0 mm X 12mm) non-sterile ERI tissue-level implants (OCO Biomedical, Inc. Albuquerque, U.S.A.) were used. Seven holes were drilled in each model following a flapless protocol using a tissue punch with a sequence of $2 \mathrm{~mm}$, 3mm and $3.7 \mathrm{~mm}$ drills (OCO Biomedical, Inc. Albuquerque, U.S.A.). A ratchet wrench was engaged to ERI driver to drive the implants to its final position just below the gum level. The implants $(\mathrm{n}=14)$ were divided into two main groups according to the cementation technique $(n=7)$ :

Group A: Seven copings were cemented using the nonvented tack cure technique.

Group B: Seven copings were cemented using the occlusal vent hole technique. 
For fabrication of the metal copings, the plastic copings for group A were left intact without drilling any vent holes but for group B vent holes were drilled occlusally with $1 \mathrm{~mm}$ round bur (15) on the castable plastic copings. All the copings were sprued, invested and casted in non-precious nickel-chromium metal alloy (Realloy e.k, Sliemsdyk 50, Krefeld, Germany). Devesting and ultrasonic cleaning was performed, residual investment material was removed using an ultrasonic cleaner and airborne-particle abraded using 50-Mm aluminum oxide particles. The metal copings were weighted before cement loading using analytical digital balance with readability of 0.0001 g (AS220.R2, RADWAG BALANCES AND SCALES, Radoom, Poland). One click of RelyX U200 resin cement clicker dispenser $\left({ }^{\mathrm{TM}} 3 \mathrm{M}\right.$, ESPE Dental Products. St. Paul, U.S.A.) was dispensed to standardize the amount of cement used. The metal copings were loaded with the resin cement and their weights were recorded using the analytical digital balance. The exact amount of cement loaded was calculated. For Group A (non-vented tack cure technique), metal copings were placed on the corresponding abutments with a fixed load of $5 \mathrm{~kg}$ and kept in place for 3 minutes to be cemented to the abutments using a static load applicator (Device used to hold the specimen under static load designed by Dr. Amir Azer, Conservative Dentistry Department consisting of strong metal coil attached from the upper end to plastic plate to put the load on, and from its lower end to a loading member to transfer the load to the specimen) (16) (figure $1 \mathrm{~A}$ ). The excess resin cement was initially light cured for 3 seconds (17) with Elipar ${ }^{\text {TM }}$ LED curing unit (3M-ESPE, St. Paul, MN, USA.) with a light output (1200) $\mathrm{mW} / \mathrm{cm}^{2}$, then excess cement on the margins were peeled off at a gel state by a Teflon coated scaler (Figure $1 \mathrm{~B}$ and $\mathrm{C}$ ).

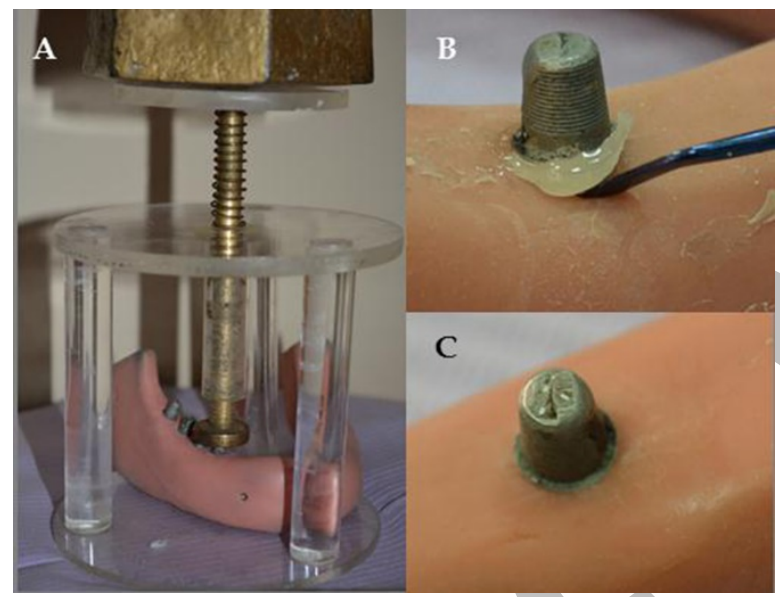

Figure 1: (A) The static load device. (B) Excess cement peeled after tack cure cementation of group A. (C) The coping after cleaning and removal of the excess cement.

For Group B (occlusal vent technique), the excess cement that flowed out from the vent was removed using cotton pellet (15) then a fixed load of $5 \mathrm{~kg}$ was applied and kept in place for 3 minutes to cement the copings to the abutments using a static load applicator. Excess cement on the margins after application of the load was removed by Teflon coated scaler and super floss (Figure 2).

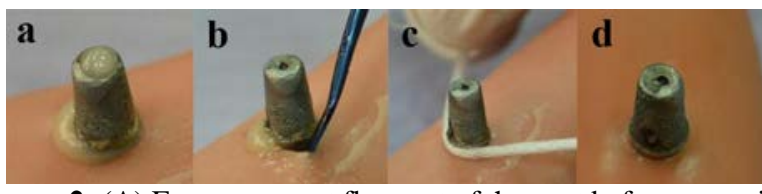

Figure 2: (A) Excess cement flow out of the vent before removing it with cotton.

(B) Excess cement on the margins removed by Teflon coated scaler. (C) Super floss used to remove the remaining excess cement. (D) The coping after total cleaning of the excess cement with Teflon coated scaler and super floss.

A proper visual examination of all groups at the coping implant interface was done to be sure that no excess cement remained, then complete light curing of the dual cure resin cement was performed for 20 seconds for each surface. The rubber surfaces on the models were sectioned using a scalpel and removed for the inspection of the cervical part of each implant for any residual excess cements (Figure 3). Cement remnants were carefully cleared with scalpel and collected to be weighted using the analytical digital scale $(16,18)$. The weight of excess cement for each implant was recorded and excess cement percentage was calculated (as following: excess cement remnants weight / amount of cement loaded weight X 100) and statistically analyzed.

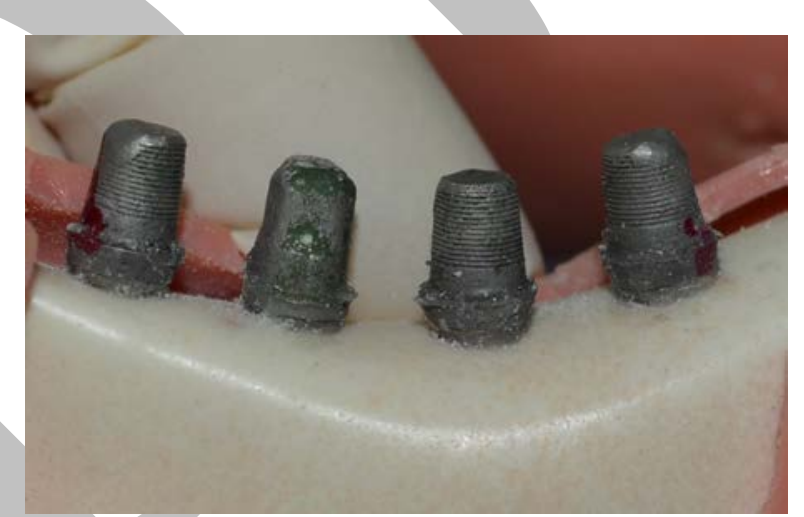

Figure 3: Excess resin cement found after removal of the artificial gingiva.

All specimens were visually examined from all sides under 30x magnification using Stereomicroscope (SZ-11, Olympus, Japan). Any remnants of cement were documented and photographed using a digital camera (E-330, Olympus, Japan) attached to the microscope.

\section{STATISTICAL METHODOLOGY}

Data were collected and entered to the computer using SPSS (Statistical Package for Social Science) program for statistical analysis (ver 21) (19). Data were entered as numerical. Data were described using minimum, maximum, median and inter-quartile range. Comparisons were carried out between two studied independent groups using MannWhitney U test (20). Box and Whisker graph was used.

An alpha level was set to $5 \%$ with a significance level of $95 \%$, and a beta error accepted up to $20 \%$ with a power of study of $80 \%$.

\section{RESULTS}

Although we tried to remove all the excess cement during the cementation process, when sectioning the rubber surfaces we found excess cement that escaped in the tissue level implants around the finish line. The amount of cement loaded for each implant in both groups (A) and (B) was: 0.0455 g. Excess cement percentage of the non-vented tack cure group (A) 
ranged from (3.5165-18.0220) \% with a median (5.0549) \% and inter-quartile range (4.3956- 16.0440) \%. While Excess cement percentage of the occlusal vent group (B) ranged from (13.6264 -24.1758) \% with a median (19.7802) \% and interquartile range (13.8462 - 23.7363) \%. Mann-Whitney U test revealed that the occlusal vent group (B) showed more excess cement percentage than the non-vented tack cure group $(\mathrm{A})$ and the difference was statistically significant. $\left(Z_{(\mathrm{MW})}=2.366\right.$ $\mathrm{p}=0.018$ ) (Table 1) (Figure 4).

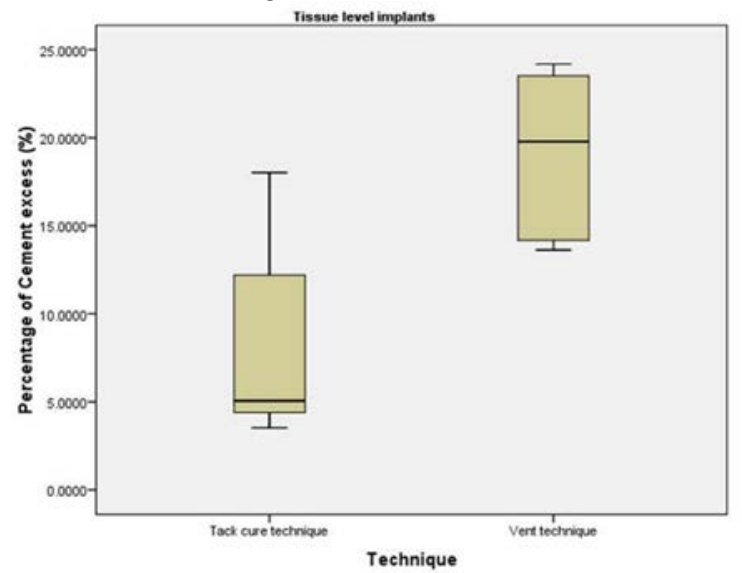

Figure 4: Box and whisker graph of cement excess percentage (\%) in the tissue level implant groups, the thick line in the middle of the box represents the median, the box represents the inter-quartile range (from $25^{\text {th }}$ to $75^{\text {th }}$ percentiles), the whiskers represents the minimum and maximum.

Table (1): Comparative study between tissue level non vented tack cure group $A$ and occlusal vent group $B$ in the excess cement percentages.

\begin{tabular}{|c|c|c||}
\hline \multirow{2}{*}{$\begin{array}{c}\text { Cement excess } \\
\text { percentage (\%) }\end{array}$} & \multicolumn{2}{|c|}{ Group } \\
\cline { 2 - 3 } & $\begin{array}{c}\text { Tissue level } \\
\text { implants non } \\
\text { vented tack } \\
\text { cure technique }\end{array}$ & $\begin{array}{c}\text { Tissue level } \\
\text { implants occlusal } \\
\text { vent technique }\end{array}$ \\
\hline $\mathrm{n}$ & 7 & 7 \\
\hline Min-Max & $3.5165-18.0220$ & $13.6264-24.1758$ \\
\hline Mean \pm S.D. & $8.5400 \pm 6.0275$ & $18.9953 \pm 4.8978$ \\
\hline $95 \%$ CI of the mean & $2.9655-14.1145$ & $14.465-23.5249$ \\
\hline Median (IQR) & $\begin{array}{c}5.0549(4.3956- \\
16.0440)\end{array}$ & $\begin{array}{c}19.7802(13.8462- \\
23.7363)\end{array}$ \\
\hline $\begin{array}{c}\text { KS test of normality } \\
\text { D=0.290, } \\
\mathrm{p}=0.077 \mathrm{NS}\end{array}$ & $\begin{array}{c}\mathrm{D}=0.249, \mathrm{p}=0.200 \\
\text { NS }\end{array}$ \\
\hline $\begin{array}{c}\text { Test of significance } \\
(\boldsymbol{p} \text { value) }\end{array}$ & \multicolumn{2}{|c|}{$\mathrm{Z}_{(\mathrm{MW})}=2.366$} \\
\hline
\end{tabular}

n: number of specimens $\quad$ Min-Max: Minimum-Maximum CI: Confidence interval IQR: Inter-quartile range

KS: Kolmogorov-Smirnov test of normality MW: Mann-Whitney U test

NS: Statistically not significant $(p \geq 0.05) *$ : Statistically significant $(p<0.05)$

Stereomicroscope examination at 30x magnification showed all the implants of both group A and B had small amounts of cement remnants remained microscopically. We noticed that group (B) had completely seated copings margins in all the implants while group (A) showed gap in four implants between the coping margins and the implants (Figure 5).

\section{DISCUSSION}

This study was an attempt to find the approach to use the resin cement in bonding the casted copings to the abutments of implants at the tissue level without leaving any resin cement remnants that may affect the periodontium and implant health. Special models simulating the bone of the mandible with an artificial gingiva covering were selected for our study to imitate the clinical situation to get comparable results. Tissue level non-sterile implants were selected for this study because of their favorable implantabutment junction positions, with this restoration-implant junction position the cementation of the implant prosthesis will resemble the conventional crown and bridge prosthetics, and thus easy to control by the clinician (21). As it was found that the increase in cement remnants was detected when the crown-abutment margin was located more submucosally $(18,21-24)$.

When comparing the two methods of cementation used in the current study, the results showed that the excess cement percentage was more with the occlusal vent technique than with the non-vented tack cure technique, and the difference was statistically significant. This might be due to removing the excess soft resin cement from the margins of the oclussal vent group was a difficult and an uncontrolled procedure (17) that may pushed the cement unintentionally further more subgingivally. This coincides with Pereira et al (25) who found that the photo-activation (tack cure) prior to cement removal had possibly facilitated the explorer to remove the excess cement before the final photo-activation. And also with Mansour et al (26) who found that flicking-off the partially polymerized excess luting resin cement with a plastic hand instrument had removed the cement cleanly away from the surface of the tooth. And also with Hatrick et al (27), Michelle and Armin (28) and Kaufman (29) who advised the light curing of the excess resin cement for several seconds to facilitate the excess removal.

The stereomicroscope results in our study showed close fitting of all the vented copings to the implant abutments, this could be the effect of the vent in decreasing the hydraulic pressure created during seating of the restoration (30). This finding was in accordance with Clark et al (31) who recommended the use of vents to reduce the excess cement pressure in the ceramic crowns, and also with Yeung et al (32) who found that the use of venting significantly decreased the cement excess and enhanced the marginal fit of implant abutments. Jones et al (33), Cooper et al (34) and Yeun and Wilson (35) also agreed with this finding as they found that the marginal adaptation of vented crowns was significantly better than that observed for non-vented crowns.

\section{CONCLUSION}

Following removal of excess luting resin cement using two methods of cementation, small amounts of cement remained adherent to the surface of all specimens at the coping-implant interface. Within the limitations of this in vitro study, it was concluded that tack curing of excess resin cement during the cementation of implant-supported restorations will reduce the cement residue, but still couldn't remove the problem of excess resin cement around dental implants. 


\section{CONFLICT OF INTEREST}

The authors declare that they have no conflicts of interest.

\section{REFERENCES}

1. Shapoff CA, Lahey BJ. Crestal bone loss and the consequences of retained excess cement around dental implants. Compend Contin Educ Dent. 2012;33: 94-6.

2. Linkevicius T, Puisys A, Vindasiute E, Linkeviciene L, Apse P. Does residual cement around implant-supported restorations cause peri-implant disease? A retrospective case analysis. Clin Oral Implants Res. 2013;24:1179-84.

3. Linkevicius T, Vindasiute E, Puisys A, Linkeviciene L, Maslova N, Puriene A. The influence of the cementation margin position on the amount of undetected cement. A prospective clinical study. Clin Oral Implants Res. 2013;24:71-6.

4. Oh TJ, Yoon J, Misch CE, Wang HL. The causes of early implant bone loss: myth or science? J Periodontol. 2002;73:322-33

5. Mombelli A, Lang N. The diagnosis and treatment of periimplantitis. Periodontol 2000. 1998;17:63-76.

6. Wolfart M, Wolfart S, Kern M. Retention forces and seating discrepancies of implant-retained castings after cementation. Int J Oral Maxillofac Implants. 2006;21:51925.

7. Frisch E, Ratka-Krüger P, Weigl P, Woelber J. Minimizing excess cement in implant-supported fixed restorations using an extraoral replica technique: a prospective 1-year study. Int J Oral Maxillofac Implants. 2015;30:1355-61.

8. Shortall AC, Fayyad MA, Williams JD. Marginal seal of injection-molded ceramic crowns cemented with three adhesive systems. J Prosthet Dent. 1989;61:24-7.

9. White SN, Sorensen JA, Kang SK, Caputo AA. Microleakage of new crown and fixed partial denture luting agents. J Prosthet Dent. 1992; 67: 156-61.

10. White SN, Yu Z, Tom JF, Sangsurasak S. In vivo microleakage of luting cements for cast crowns. J Prosthet Dent. 1994;71:333-8.

11. Agar JR, Cameron SM, Hughbanks JC, Parker MH. Cement removal from restorations luted to titanium abutments with simulated subgingival margins. J Prosthet Dent. 1997;78:43-7.

12. Fox SC, Moriarty JD, Kusy R. The effects of scaling a titanium implant surface with metal and plastic instruments: an in vitro study. J Periodontol. 1990;61:485-90.

13. Liang T, Hu X, Zhu L, Pan X, Zhou Y, Liu J. Comparative in vitro study of cementing techniques for implantsupported restorations. J Prosthet Dent. 2016;116:59-66.

14. Schwedhelm ER, Lepe X, Aw TC. A crown venting technique for the cementation of implant-supported crowns. J Prosthet Dent. 2003;89:89-90.

15. Begum Z, Sonika R, Pratik C. Effect of different cementation techniques on retained excess cement and uniaxial retention of the implant-supported prosthesis: an in vitro study. Int J Oral Maxillofac Implants. 2014;29:13337.

16. Corrales RJ, Koudriavtsev TV. Effect of preseating on the extrusion of excess cement at the crown abutment margin and the associated tensile force for cement retained implant restorations. A pilot study. Int J Dent Sci. 2015;43-51.

17. Sunico-Segarra M, Segarra A. Clinical Procedures. In: A Practical Clinical Guide to Resin Cements. Berlin, Heidelberg: Springer; 2015.
18. Linkevicius T, Vindasiute E, Puisys A, Peciuliene V. The influence of margin location on the amount of undetected cement excess after delivery of cement-retained implant restorations. Clin Oral Implants Res. 2011;22:1379-84.

19. IBM Corp. IBM SPSS Statistics for Windows, Version 21.0. Armonk, NY: IBM Corp.; Released 2012.

20. Mann HB, Whitney DR. On a test of whether one of two random variables is stochastically larger than the other. Ann Math Stat. 1947: 50-60.

21. Buser D, Schmid B, Belser UC, Cochran DL. The new bone level implants - clinical rationale for the development and current indications for daily practice. Int Dent SA. 2010;12:58-66.

22. Kappel S, Eiffler C, Lorenzo-Bermejo J, Stober T, Rammelsberg P. Undetected residual cement on standard or individualized all-ceramic abutments with cemented zirconia single crowns - a prospective randomized pilot trial. Clin Oral Implants Res. 2016;27:1065-71.

23. Sancho-Puchades M, Crameri D, Ozcan M, Sailer I, Jung RE, Hammerle CHF, Thoma DS. The influence of the emergence profile on the amount of undetected cement excess after delivery of cement-retained implant reconstructions. Clin Oral Implants Res. 2017;1-8.

24. IOSR Journal of Dental and Medical Sciences. A Clinical Evaluation to Assess the Amount of Residual Excess Cement when Using Prefabricated and Custom Fabricated Implant Abutment and a Modified Final Restoration. J Dent Med Sci. 2017;16:86-91.

25. Pereira SMB, Anami LC, Pereira CA, Souza ROA, Kantorski KZ, Bottino MA, et al. Bacterial Colonization in the Marginal Region of Ceramic Restorations: Effects of Different Cement Removal Methods and Polishing. Operative Dent. 2016;6:64254.

26. Mansour YF, Pintado MR, Mitchell CA. Optimizing resin cement removal around esthetic crown margins. Randomized controlled trial. Acta Odontol Scand. 2006;64:231-6.

27. Hatrick CD, Eakle WS, Bird WF. Dental Materials: Clinical Applications for Dental assistants and Dental Hygienists. USA: Elsevier Health Sciences; 2015. 384.

28. Michelle S, Armin S. A Practical Clinical Guide to Resin Cements. Berlin Heidelberg: Springer-Verlag; 2015.

29. Kaufman L. Proper Clean-Up: Removing Excess/Residual Resin-Based Dental Cement. Dent Learn. 2015;3:49-51.

30. McAllister BS. Rationale for the Vented-crown Technique and its Application in Today's Dental Practice. Operative Dent 2008;2:116-20.

31. Clark MT, Richards MW, Meiers JC. Seating accuracy and fracture strength of vented and non-vented ceramic crowns luted with three cements. J Prosthet Dent 1995;74:18-23.

32. Yeung TC, Lai YL, Hsieh YL, Lee SY. The effect of cement and venting design on the retentive strength and marginal adaptation of CeraOne implant prostheses. Chin Dent J 2005;24:95-100.

33. Jones MD, Dykema RW, Klein AI. Television micromeasurement of vented and non-vented cast crown marginal adaptation. Dent Clin North Am. 1971;15:663-77.

34. Cooper TM, Christensen GJ, Laswell HR. Effect of venting on cast gold full crowns. J Prosthet Dent. 1971;26:621-5.

35. Yeun TWH, Wilson PR. The effect of venting on pulpward pressure transmission and seating on crown cementation: a laboratory study. J Oral Rehabil. 2000;27:958-66. 